\title{
Bacterial Proteases as Thrombolytics and Fibrinolytics
}

\author{
Taqiyah Akhtar' ${ }^{1}$ Md. Mozammel Hoq ${ }^{2}$ and Md. Abdul Mazid ${ }^{1}$
}

${ }^{1}$ Department of Pharmaceutical Chemistry, University of Dhaka, Dhaka-1000, Bangladesh

${ }^{2}$ Department of Microbiology, University of Dhaka, Dhaka-1000, Bangladesh

(Received: September 05, 2017; Accepted: November 07, 2017; Published (web): December 23, 2017)

\begin{abstract}
Proteases regulate important pathophysiological processes in human body such as homeostasis, blood coagulation, fibrinolysis, tumor progression, etc. These biological effects of proteases largely attribute to their applicability as therapeutic agents. Imbalance in blood coagulation and fibrinolysis, two important physiological processes in human body, leads to thrombosis, a leading cause of cardiovascular complications including myocardial infarction, stroke, etc. The enzymes used to dissolve thrombus (blood clot) are known as thrombolytic agents and among them, the enzymes involving hydrolysis of fibrin called fibrinolytic agents. Thrombolytic agents can be classified according to generation, mechanism of action, source and active site of the enzymes. Among the commercially available thrombolytic agents, uPA and tPA are generally safe but are very expensive. On the other hand, the bacterial streptokinase is a relatively cheap thrombolytic agent but causes undesirable side effects such as bleeding complications. For this reason, worldwide research for potent thrombolytic agents to prevent and treat cardiovascular diseases have been continuing. Microbes are considered as a potential source of as well as safe vectors for expressing thrombolytic and fibrinolytic enzymes. Bacilli are one of the largest groups for this purpose. They have been collected from different traditional fermented foods or have been produced by solid state fermentation using appropriate nutrient substrates including different agro-industrial wastes such as rice straw, molasses, soybean curd residues, etc. This review focuses on different bacterial proteases reported to have potential thrombolytic and fibrinolytic activities.
\end{abstract}

Key words: Bacterial proteases, fibrinolysis, thrombolytic agents, thrombosis.

Proteases are among the most diverse families of enzymes that catalyze the breakdown of peptide bonds in a protein. They are also called proteinases, peptidases or proteolytic enzymes. ${ }^{1}$ This family of enzyme contains a very large and complex group of hydrolytic enzyme and usually catalyzes hydrolysis of proteins. According to Enzyme Commission (EC) number proposed by International Union of Biochemistry and Molecular Biology (IUBMB), enzymes have been classified into six groups. Proteases belong to EC number 3.4 where EC 3 enzymes are hydrolases enzymes and EC 3.4 are those hydrolases that act on peptide bonds. On the basis of the site of action, they can be divided into exopeptidases and endopeptidases ${ }^{2}$, while on the basis of optimal $\mathrm{pH}$ range for their activity, proteases

Correspondence to: Md. Abdul Mazid

Email: ma.mazid@du.ac.bd

Dhaka Univ. J. Pharm. Sci. 16(2): 255-269, 2017 (December) can be classified as acid proteases ( $\mathrm{pH}$ optima 2-5), neutral proteases ( $\mathrm{pH}$ optima 7) and alkaline proteases ( $\mathrm{pH}$ optima 8-11). ${ }^{3}$ On the other hand, according to the active site, proteases are classified into seven broad groups: serine proteases, cysteine proteases, threonine proteases, aspartic proteases, glutamic proteases, metalloproteases, and asparagine peptide lyases. ${ }^{4}$ Proteases having fibrinolytic and thrombolytic activities are principally serine proteases and metalloproteases.

Proteases are necessary in every aspect of cellular and biological systems. They are ubiquitous and are found in plants, animals and microbes. Based on their presence in living system, they are classified into two groups: intracellular proteases and extracellular proteases. Extracellular enzymes were originally considered as enzymes and used in industry, while intracellular proteases are considered to regulate biochemical reactions in living system. In 
human body, up-regulation of proteolysis is involved in tumor initiation, progression and metastasis, and causes different types of cancer ${ }^{5}$, while dysregulation of proteolysis is involved in various inflammatory and other diseases. ${ }^{6}$ Besides industrial uses, proteases are used as health care product, in diagnostic kit development, and of course as therapeutics in the treatment of various diseases. ${ }^{7}$ Since 1978, a number of proteases have been approved by Food and Drug Administration (FDA) for therapeutic applications (Table 1$)^{6}$ and many are now in clinical trial. Microorganisms have been considered as preferred sources of the proteases. Bacterial proteases are more

Table 1. List of FDA approved therapeutic proteases.

\begin{tabular}{|c|c|c|c|c|c|c|c|}
\hline $\begin{array}{l}\text { Type of } \\
\text { protease }\end{array}$ & $\begin{array}{l}\text { Name of } \\
\text { protease }\end{array}$ & Brand name & Manufacturer & $\begin{array}{l}\text { Mechanism of } \\
\text { action }\end{array}$ & $\begin{array}{l}\text { Therapeutic } \\
\text { indication }\end{array}$ & $\begin{array}{l}\text { Year of } \\
\text { FDA } \\
\text { approval }\end{array}$ & Source \\
\hline \multirow{16}{*}{ Serine } & $\mathrm{u}-\mathrm{PA}$ & Abbokinase ${ }^{\circledR}$ & Abbott Labs. & $\begin{array}{l}\text { Activates } \\
\text { plasminogen }\end{array}$ & Catheter clearing & 1978 & $\begin{array}{l}\text { Urine or primary } \\
\text { cell kidney culture }\end{array}$ \\
\hline & $\mathrm{t}-\mathrm{PA}$ & Activase®, & Genentech, Inc. & Activates & AMI & 1987 & \multirow{3}{*}{$\begin{array}{l}\text { Recombinant, } \\
\text { expressed in } \mathrm{CHO} \\
\text { cells }\end{array}$} \\
\hline & (Alteplase) & Cathflo & & plasminogen & Stroke & 1996 & \\
\hline & & Activase® & & & Catheter clearing & 2002 & \\
\hline & Reteplase & Retavase $\AA$, & Boehringer & Activates & AMI & 1996 & Recombinant, \\
\hline & & Rapilysin & $\begin{array}{l}\text { Mannheim } \\
\text { GmbH }\end{array}$ & plasminogen & & & $\begin{array}{l}\text { expressed in } \boldsymbol{E} \text {. } \\
\text { coli }\end{array}$ \\
\hline & TNK-tPA & $\begin{array}{l}\text { TNKase }^{\mathrm{TM}}, \\
\text { Metalyse }\end{array}$ & Genentech, Inc. & $\begin{array}{l}\text { Activates } \\
\text { plasminogen }\end{array}$ & $\mathrm{Ml}$ & 2000 & $\begin{array}{l}\text { Recombinant, } \\
\text { expressed in } \mathrm{CHO} \\
\text { cells }\end{array}$ \\
\hline & \multirow[t]{2}{*}{ FIX } & \multirow[t]{2}{*}{ BeneFIX® } & \multirow[t]{2}{*}{ Pfizer } & \multirow[t]{2}{*}{ Activates FX } & \multirow[t]{2}{*}{ Haemophilia B } & 1990 & Human plasma \\
\hline & & & & & & 1997 & $\begin{array}{l}\text { Recombinant, } \\
\text { expressed in } \mathrm{CHO} \\
\text { cells }\end{array}$ \\
\hline & FVIIa & $\begin{array}{l}\text { NovoSeven } \AA \text {, } \\
\text { NovoSeven }{ }^{\circ} \\
\text { RT }\end{array}$ & $\begin{array}{l}\text { Novo Nordisk } \\
\text { Pharmaceuticals } \\
\text { Inc. }\end{array}$ & $\begin{array}{l}\text { Activates FX } \\
\text { and FIX }\end{array}$ & $\begin{array}{l}\text { Haemophilia A } \\
\text { and B }\end{array}$ & 1999 & $\begin{array}{l}\text { Recombinant, } \\
\text { expressed in } \mathrm{BHK} \\
\text { cells }\end{array}$ \\
\hline & $\begin{array}{l}\text { Topical } \\
\text { thrombin in } \\
\text { bandages }\end{array}$ & $\begin{array}{l}\text { THROMBIN- } \\
\text { JMI }\end{array}$ & GenTrac & $\begin{array}{l}\text { Activates } \\
\text { fibrinogen }\end{array}$ & Bleeding & 2006 & Bovine \\
\hline & Thrombin & Recothrom ${ }^{\circledR}$ & $\begin{array}{l}\text { ZymoGenetics, } \\
\text { Inc. }\end{array}$ & $\begin{array}{l}\text { Activates } \\
\text { fibrinogen }\end{array}$ & Bleeding & 2008 & $\begin{array}{l}\text { Recombinant, } \\
\text { expressed in } \mathrm{CHO} \\
\text { cells }\end{array}$ \\
\hline & $\begin{array}{l}\text { Activated } \\
\text { protein } \mathrm{C},\end{array}$ & $\begin{array}{l}\text { Drotrecogin } \\
\text { alfa, Xigris } ®\end{array}$ & $\begin{array}{l}\text { Eli Lilly and } \\
\text { Company }\end{array}$ & $\begin{array}{l}\text { Activates } \\
\text { plasminogen }\end{array}$ & $\begin{array}{l}\text { Sepsis, septic } \\
\text { shock }\end{array}$ & $\begin{array}{l}2001 \\
\text { (but } \\
\text { withdra } \\
\text { wn on } \\
\text { Oct. 25, } \\
\text { 2011) }\end{array}$ & $\begin{array}{l}\text { Recombinant, } \\
\text { expressed in human } \\
\text { cell line }\end{array}$ \\
\hline & \multirow[t]{3}{*}{ Pancrelipase } & Creon ${ }^{\circledR}$ & Abbvie (Abbott) & \multirow{3}{*}{$\begin{array}{l}\text { Helps in protein } \\
\text { digestion }\end{array}$} & \multirow{3}{*}{$\begin{array}{l}\text { Exocrine } \\
\text { Pancreatic } \\
\text { Insufficiency }\end{array}$} & \multirow[t]{3}{*}{2009} & \multirow{3}{*}{$\begin{array}{l}\text { Porcine pancreatic } \\
\text { extract }\end{array}$} \\
\hline & & Zenpep® & Actavis & & & & \\
\hline & & Pancreaze ( & $\begin{array}{l}\text { Ortho-McNeil- } \\
\text { Janssen } \\
\text { Pharmaceuticals } \\
\text { Inc. }\end{array}$ & & & & \\
\hline \multirow{2}{*}{$\begin{array}{l}\text { Metallo- } \\
\text { protease } \\
\text { (zinc) }\end{array}$} & $\begin{array}{l}\text { Botulinum } \\
\text { toxin A }\end{array}$ & Botox ${ }^{\circledR}$ & Allergan & $\begin{array}{l}\text { Deactivates } \\
\text { Syntaxin and } \\
\text { SNAP-25 }\end{array}$ & $\begin{array}{l}\text { Various muscle } \\
\text { spasms }\end{array}$ & 1989 & $\begin{array}{l}\text { Bacterial }(C . \\
\text { botulinum })\end{array}$ \\
\hline & $\begin{array}{l}\text { Botulinum } \\
\text { toxin B }\end{array}$ & Myobloc & $\begin{array}{l}\text { Solstice } \\
\text { Neurosciences }\end{array}$ & $\begin{array}{l}\text { Deactivates } \\
\text { Synaptobrevin }\end{array}$ & $\begin{array}{l}\text { Cervical } \\
\text { dystonia }\end{array}$ & 2000 & $\begin{array}{l}\text { Bacterial }(C . \\
\text { botulinum) }\end{array}$ \\
\hline
\end{tabular}

FDA=US Food and Drug Administration; u-PA=urokinase type Plasminogen Activator; t-PA=tissue type Plasminogen Activator;TNKtPA=Tenecteplase; FIX=Factor IX; FVIIa=activated Factor VII;AMI=Acute Myocardial Infarction;MI= Myocardial infarction; $\mathrm{CHO}=$ Chinese hamster ovary; $\mathrm{BHK}=$ baby hamster kidney 
significant than animal or fungal proteases and a large number of bacterial species are known to produce serine-type alkaline proteases. ${ }^{8}$ Proteases are also used as useful agents in the treatment of sepsis, digestive disorders, inflammation, cystic fibrosis, psoriasis, etc. besides having predominant use in treating cardiovascular diseases (CVDs). ${ }^{6}$

Thrombus is a blood clot formed inside the blood vessel by a process called thrombosis. Thrombus formation is one of the major causes of cardiovascular diseases (CVDs), for example, myocardial infarction (commonly known as heart attack), stroke, transient ischemic attack (TIA), venous thromboembolism (VTE) including deep vein thrombosis (DVT), pulmonary embolism (PE), etc. CVDs are the major causes of death globally. ${ }^{9}$ As a result, thrombolytic and fibrinolytic agents are gaining more interests day by day. Among the thrombolytic agents, fibrinolytic proteases are considered as the potent agents to treat and prevent CVDs. ${ }^{10}$

Blood clotting is a normal physiological process to prevent hemorrhage. Fibrin is the major component of blood clot which is formed from fibrinogen via proteolysis by thrombin. On the other hand, fibrin clots are hydrolyzed by plasmin to avoid thrombosis in blood vessels. During an unbalanced pathophysiological process, hydrolysis of clots may not occur which lead to thrombosis (formation of blood clot). ${ }^{11}$

\section{Process of blood clotting or thrombus formation}

Hemostasis is a process of cessation of blood loss by forming a clot. An obstructive clot when formed inside a blood vessel is called thrombus formation. ${ }^{12}$ Hemostasis can be divided into two types: primary hemostasis (immediate platelet activation) and secondary hemostasis (additional coagulation cascade to form fibrin strands). ${ }^{13}$ When circulating platelets are exposed directly to the collagen of damaged endothelium, they bind to collagen with different surface glycoproteins. It results in activation of platelet integrins which adhere platelets to the site of injury. ${ }^{14}$ Activated platelets change shape from spherical to stellate. They release some chemicals including platelet activating factor (PAF), secretonin, thromboxane $\mathrm{A}_{2}$, etc to activate additional platelets and to subsequently increase the affinity of platelets to bind fibrinogen. ${ }^{15}$

Secondary hemostasis involves sequential activation of different inactive enzyme precursors known as zymogens by proteolytic activity in which each activate enzyme causes activation of another zymogen ${ }^{15}$ which lead to coagulation of blood. The coagulation cascade is divided into three pathways: (i) tissue factor pathway (or extrinsic pathway) (ii) contact activation pathway (or intrinsic pathway) and (iii) final common pathway. ${ }^{16}$ Active FX and FV form a prothrombinase complex with prothrombin which is a proteolytic enzyme that activates prothrombin zymogen to active thrombin. ${ }^{17,18}$

During tissue factor pathway, thrombin is formed very rapidly and the amount of FVIIa in blood is higher than other coagulation factors. The main function of thrombin is to convert inactive fibrinogen zymogen to active fibrin monomer which then form hemostatic plug with other constituents. Thrombin also has other functions such as platelet activation, activation of FVIII, FV protein $\mathrm{C}$ (in presence of thrombomodulin), FXIII (which helps fibrin polymer to form covalent bond to crosslink) zymogens. ${ }^{15}$

\section{Thrombolysis and fibrinolysis}

The term thrombolysis generally refers to the dissolution of the thrombus while the term fibrinolysis generally refers to the breakdown of fibrin in the blood clot. Fibrin is the end product of the coagulation cascade. Fibrin is dissolved by enzyme plasmin which is a serine protease similar to trypsin. Plasmin is the activated form of plasma zymogen, plasminogen. In human, plasminogen is available as two major glycoforms: type I plasminogen contains two glycosylation molecules and type II plasminogen contains a single glycosylated molecule. ${ }^{19}$ When circulating plasminogen binds to cell surface or blood clot, it adopts an open conformation which is cleaved 
between Arg-561 and Val-562 to form active plasmin. This cleavage is done by a variety of enzymes like tissue plasminogen activator (tPA), urokinase-type plasminogen activator (uPA), Kallikrein and factor XII. ${ }^{20,21,22,23}$ After plasmin is formed, fibrin is cleaved giving soluble degradation products $^{24}$ (Figure 1). That means fibrinolysis occurs in two phases: in the first phase, plasminogen is activated on the fibrin clot surface to form plasmin which dissolved fibrin ${ }^{25}$ in the second phase, exposing additional binding sites of degraded fibrin leading to amplification of the clot breakdown by plasmin. The primary fibrinolysis is a normal body process, but secondary fibrinolysis occurs due to pharmacological means such as by thrombolytics and fibrinolytics. $^{26}$

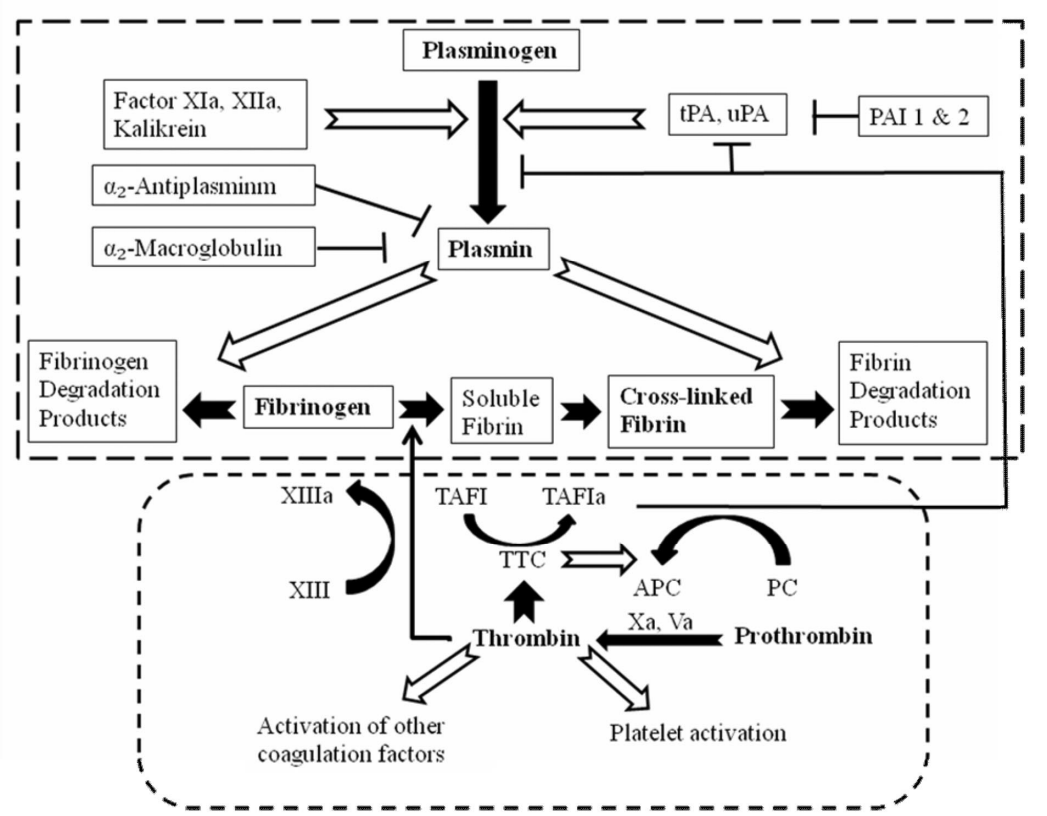

Figure 1. Mechanism of fibrinolysis. tPA= Tissue tipe plasminogen activator; $\mathrm{uPA}=$ Urokinase type plasminogen activator; $\mathrm{PAI}=$ Plasminogen activator inhibitor; XI=Plasma thromboplastin, an antecedent serine protease; XII=Hageman factor, a serine protease; $\mathrm{XIII}=$ Fibrin stabilising factor, a transglutaminase; TAFI= thrombin-activatable fibrinolysis inhibitor; TTC $=$ Thrombomodulinthrombin complex; $\mathrm{PC}=$ Protein $\mathrm{C} ; \mathrm{APC}=$ Activated protein $\mathrm{C}, \mathrm{a}=$ Activated form.

\section{Thrombolytic agents: Classification and sources}

Thrombolytic agents are the drugs that are used to dissolve blood clots or thrombus formed inside blood vessel, and reopen the vessels (artery or vein). Various CVDs including heart attack, stroke, deep vein thrombosis (clot in a deep leg vein), pulmonary embolism, etccan be treated using thrombolytic agents. Reteplase (rPA or Retavase), alteplase (tPA or Activase), urokinase (Abbokinase), prourokinase, anisoylated purified streptokinase activator complex (APSAC) and streptokinase are available thrombolytic agents (Table 6). On the other hand, all available thrombolytic agents are also classified as $1^{\text {st }}, 2^{\text {nd }}, 3^{\text {rd }}$ and $4^{\text {th }}$ generation thrombolytic agents. ${ }^{27,28}$ Fibrinolytic agents sometimes are also classified into two categories: Fibrin specific agents and non-fibrin specific agents $^{29}$ (Table 2).

However, different thrombolytic agents have different working mechanisms. Based on these mechanisms, the thrombolytic agents are classified into two types. i) Plasminogen activators, which activate plasminogen into active plasmin to degrade fibrin. They may present naturally in blood such as tissue-type plasminogen activator $(\mathrm{tPA})^{30}$ and urokinase-type plasminogen activator ${ }^{31}$, or may be obtained from bacterial sources, e.g. streptokinase. ii) plasmin-like proteins, which directly degrade the fibrin in blood clots, thereby dissolving the thrombi rapidly and completely. Lumbrokinase from earthworm and fibrolase from snake venom are well- 
known plasmin-like proteins. ${ }^{32,33}$ On the other hand, based on active site, thrombolytic agents are classified into i) serine protease (NK, subtilisin DFE, and $\mathrm{CK}$ ) ii) metalloprotease (jeot-gal enzyme, AMMP, and Bacillokinase II), and iii) both serine and metalloprotease (R. chinensis 12 and Streptomyces sp. Y405) ${ }^{34,35}$ Thrombolytic agents can be obtained from animal cells, plasma, urine or microorganisms.

The microorganisms producing fibrinolytic enzymes include different phyllums and divisions of bacteria, fungi and algae. ${ }^{36}$ Various sources including Actinomyces thermovulgaris ${ }^{37}$, Streptomyces $\mathrm{sp}$. $\mathrm{Y}_{405^{35}}$, Streptomyces spheroids M8-2 ${ }^{38}$,

Table 2. Generation-wise classification of thrombolytic agents.
Streptomyces megasporus SD5 $5^{39,40}$, Bacillus subtilis BK- $17^{41}$, B. subtilis A $1^{42}$, B. subtilis $168^{43}, B$. thuringiensis IMV B-732444, Paenibacillus sp. IND8 ${ }^{46}$, Pseudoalteromonas sp. IND11 ${ }^{47}$, Serratia sp. KG-2-1 ${ }^{48}$, Shewanella sp. IND20 ${ }^{49}$, Aspergillus ochraceus $513^{50}$, Cochliobolus lunatus ${ }^{51}$, Fusarium oxysporum $^{52,53}$, Penicillium chrysogenum $\mathrm{H}^{54}$, Fusarium pallidoroseum ${ }^{55}$, Candida guilliermondii ${ }^{56}$, Pleurotus ostreatus ${ }^{57}$, Rhizopus chinensis $12^{58}$, Mucor subtillissimus $\mathrm{UCP} 1262^{59}$, Codium intricatum $^{60}$ and Codium latum ${ }^{61}$ have been used to screen and characterize different fibrinolytic enzymes in recent years.

\begin{tabular}{|c|c|c|c|}
\hline Generation & \multicolumn{2}{|l|}{ Thrombolytic agents } & Fibrin Specificity \\
\hline \multirow[t]{2}{*}{$1^{\text {st }}$ generation } & \multicolumn{2}{|l|}{ Streptokinase } & Non-specific \\
\hline & \multicolumn{2}{|l|}{ Urokinase } & Non-specific \\
\hline \multirow[t]{2}{*}{$2^{\text {nd }}$ generation } & \multicolumn{2}{|c|}{ Recombinant tissue plasminogen activator (t-PA) } & Specific \\
\hline & \multicolumn{2}{|c|}{ Saruplase or Prourokinase (scu-PA) } & Non-specific \\
\hline \multirow[t]{10}{*}{$3^{\text {rd }}$ generation } & Alteplase & & Specific \\
\hline & Tenecteplase (TNK-tPA) & & \\
\hline & Reteplase & & \\
\hline & Monteplase & & \\
\hline & Lanoteplase & & \\
\hline & Pamiteplase & & \\
\hline & Staphylokinase & & \\
\hline & Desmoteplase (Bat-PA) & & \\
\hline & Chimeric thrombolytics & $\begin{array}{l}\text { Staphylokinase chimeric molecule, Prourokinase } \\
\text { chimera, Chimeric t-PA/scu-PA }\end{array}$ & \\
\hline & \multicolumn{2}{|l|}{ Anistreplase } & Non-specific \\
\hline $4^{\text {th }}$ generation & \multicolumn{2}{|c|}{ Plasminogen activator inhibitors (PAIs) } & Non-specific \\
\hline
\end{tabular}

\section{Available thrombolytic agents}

A. Tissue plasminogen activator. Tissue plasminogen activator (tPA) is a serine protease and catalyzes the conversion of plasminogen to plasmin and helps in dissolving blood clot. Natural tPA are found in endothelial cells of blood vessels lining, while recombinant tPAs are obtained from microbial sources by recombinant DNA technology. They are used intravenously as thrombolytic agents. The usage of tPA in clinical applications is limited due to short half-life (4-6 min) and high cost of the treatment. tPA is produced as a single chain (sctPA) glycoprotein containing 527 amino acid which is cleaved at Arg 275-Ile276 to a disulphide linked, two chain form (tc-tPA). ${ }^{62}$ Both forms exhibit equivalent activity when fibrin bound. ${ }^{63}$ The action of tPA on plasminogen is a weak one and the affinity between t-PA and plasminogen is low in absence of fibrin, while is significantly higher in presence of fibrin. $t$ $\mathrm{PA}$ is the major intravascular activator of 
plasminogen ${ }^{64}$ and its gene expression is regulated by histamine, bytyrate, retinoids, arterial levels of shear stress and dexamethanosone independently of PAI- $1 .{ }^{19}$

The three fibrin specific, genetically engineered tissue-type plasminogen activators (r-tPAs) are alteplase, reteplase, and tenecteplase (TNKase). ${ }^{65}$ Desmoteplase, another r-tPAs are under Phase III clinical trial and the Danish pharmaceutical company, Lundbeck, holds the worldwide rights for this product. Other recombinant tPAs include lanoteplase, saruplase, anistreplase and pamiteplase (Table 3).

Table 3. Different thrombolytic agents and their comparison.

\begin{tabular}{|c|c|c|c|c|c|c|}
\hline Thrombolytic Agents & $\mathrm{t}-\mathrm{PA}$ & $\mathrm{u}-\mathrm{PA}$ & Streptokinase & Staphylokinase & Alteplase & Reteplase \\
\hline Molecular Weight & $70 \mathrm{kDa}$ & $32-54 \mathrm{kDa}$ & $47 \mathrm{kDa}$ & $16.5 \mathrm{kDa}$ & $70 \mathrm{kDa}$ & $40 \mathrm{kDa}$ \\
\hline Source & $\begin{array}{l}\text { Naturally } \\
\text { in blood }\end{array}$ & $\begin{array}{l}\text { Human } \\
\text { neonatal kidney } \\
\text { cells }\end{array}$ & $\begin{array}{l}\beta \text {-hemolytic } \\
\text { Streptococci }\end{array}$ & $\begin{array}{l}\text { Staphylococcus } \\
\text { aureus }\end{array}$ & $\begin{array}{l}\text { Recombinant DNA } \\
\text { technology from } \\
\text { human melanoma cell } \\
\text { line }\end{array}$ & $\begin{array}{l}\text { Single chain } \\
\text { deletion variant } \\
\text { of alteplase }\end{array}$ \\
\hline Proteolytic nature & Protease & Protease & Not protease & Not protease & Protease & Protease \\
\hline $\begin{array}{l}\text { Plasminogen } \\
\text { Activation }\end{array}$ & Direct & Direct & Indirect & Indirect & Direct & Direct \\
\hline Fibrin Specificity & $\mathrm{S}$ & NS & NS & $\mathrm{S}$ & $\mathrm{S}$ & $\mathrm{S}$ \\
\hline Indication & $\begin{array}{l}\text { AIS, APE, } \\
\text { STEMI }\end{array}$ & APE, MI & $\begin{array}{l}\text { STEMI APE, } \\
\text { DVT }\end{array}$ & STEMI, Stroke & AIS, APE, STEMI & STEMI \\
\hline Plasma Half-life & $3-4$ & 15 & 18 & 6 & $4-8$ & $11-14$ \\
\hline Antigenecity & No & No & Yes & Yes & No & No \\
\hline Immunogenicity & No & Unknown & No & Yes & No & No \\
\hline Side effects & Unknown & Yes & Yes & Yes & No & No \\
\hline Dosage & Unknown & $3 \mathrm{mU} / \mathrm{hr}$ & $1.5 \mathrm{mU} / \mathrm{hr}$ & $\begin{array}{l}15 \mathrm{mg}+15 \mathrm{mg} \\
\text { double bolus }\end{array}$ & $\begin{array}{l}15 \mathrm{mg} \text { bolus }+3 \mathrm{hr} \\
\text { infusion upto } 85 \mathrm{mg}\end{array}$ & $\begin{array}{l}\text { Double bolus } \\
(10 \mathrm{U}+10 \mathrm{U}, 30 \\
\text { min apart })\end{array}$ \\
\hline
\end{tabular}

Table 3 contd. right side.

\begin{tabular}{|c|c|c|c|c|c|}
\hline Tenecteplase & Lanoteplase & Saruplase & Anistreplase & Desmoteplase & Pamiteplase \\
\hline $70 \mathrm{kDa}$ & $54 \mathrm{kDa}$ & $47 \mathrm{kDa}$ & $131 \mathrm{kDa}$ & $52 \mathrm{kDa}$ & Unknown \\
\hline $\begin{array}{l}\text { Multiple (three) point } \\
\text { mutation of alteplase }\end{array}$ & $\begin{array}{l}\text { Deletion and single } \\
\text { point mution of } \\
\text { wild-type tPA }\end{array}$ & $\begin{array}{l}\text { Recombinant } \\
\text { scu-PA }\end{array}$ & $\begin{array}{l}\text { Anisoylated } \\
\text { plasminogen-SK } \\
\text { activator complex }\end{array}$ & $\begin{array}{l}\text { From the saliva of } \\
\text { the vampire bat } \\
\text { Desmodus rotundus }\end{array}$ & $\begin{array}{l}\text { Derivative in tPA } \\
\text { recombinant CHO } \\
\text { cell lines. }\end{array}$ \\
\hline Protease & Protease & Protease & Protease & Protease & Protease \\
\hline Direct & Direct & Direct & Indirect & Direct & Direct \\
\hline S & $\mathrm{S}$ & NS & NS & S & S \\
\hline STEMI, Stroke & MI & Stroke & MI & Stroke & APE \\
\hline 20 & $37+11$ & $6-9$ & $90-112$ & 190 & $30-47$ \\
\hline Unknown & Unknown & No & No & No & Unknown \\
\hline No & Unknown & No & Unknown & Yes & No \\
\hline No & Yes & Yes & Unknown & Less & Unknown \\
\hline $\begin{array}{l}0.5 \mathrm{mg} / \mathrm{kg} \text { single } \\
\text { bolus }\end{array}$ & $\begin{array}{l}120, \mathrm{kU} / \mathrm{kg} \text { single } \\
\text { bolus }\end{array}$ & $\begin{array}{l}20 \mathrm{mg} \text { bolus } \\
+60 \\
\mathrm{mg} / 60 \mathrm{~min}\end{array}$ & Unknown & $\begin{array}{l}0.125 \mathrm{mg} / \mathrm{k} \mathrm{g} \text { single } \\
\text { bolus }\end{array}$ & $\begin{array}{l}0.1 \mathrm{mg} / \mathrm{kg} \text { single } \\
\text { bolus }\end{array}$ \\
\hline
\end{tabular}

$\mathrm{APE}=$ Acute pulmonary embolism; STEMI=ST-segment elevation myocardial infarction; DVT=Deep vein thrombosis; AIS=Acute ischemic stroke; $\mathrm{S}=$ Specific; $\mathrm{NS}=$ Non-specific 
(a) Alteplase: Alteplase is the first recombinant tissue-type plasminogen activator. The US Food and Drug Administration (FDA) in 1996 approved alteplase for treatment of acute ischemic stroke (AIS). This rtPA is administered through intravenous route and is the only thrombolytic agent approved for AIS to date. This enzyme is the first clinically used tPA molecule invented by Genentech Inc marketed as Activase ${ }^{\circledR}$. It is the $1^{\text {st }}$ generation tPA and has less fibrin specificity compared to tenecteplase. ${ }^{6,66}$

(b) Reteplase: Reteplase is a second generation non-glycosylated r-tPA expressed in Escherichia coli, and was approved by FDA in 1996 for the treatment of AMI. It is a truncated form of tPA and contains 357 amino acids of 527 amino acids of original protein. The innovator Boehringer Mannheim marketed this product in the brand name Retavase®. It has reduced affinity for fibrin as well as the rate of clearance, and increased half-life (13-16 minutes) in plasma because it lacks the N-terminal fibronectin finger, the EGF domain and the first kringle domains compared with the native tPA. For this reason, reteplase can be administered as a double bolus rather than as an infusion, reducing the expense of administration and time. ${ }^{67,68}$ Reteplase has similar efficacy compared to the first-generation tPA, but has less fibrin specificity, and can be administered more conveniently than alteplase. ${ }^{6}$

(c) Tenecteplase: Tenecteplase, also known as TNK-tPA was approved by the FDA in 2000. It was invented by Genentech Inc and marketed under the brand name of TNKase ${ }^{\circledR}$. It is a genetically engineered tPA expressed in mammalian cell line, Chinese Hamster Ovary (CHO) cells. TNK-tPA was developed by site-directed mutagenesis of tPA at three sites: a substitution of an asparagines (Asn) residue for threonine (Thr) 103, a substitution of a glutamine residue (Gln) for Asn117 and tetra-alanine substitutions for residues 296-299 in the protease domain. Tenecteplase contains all protein domains present in the first-generation tPA molecule. ${ }^{69}$ However, mutation in Thr103 improves protein solubility and extends the proteases circulation halflife by creating a new N-linked glycosylation site, while mutation at Asn 117 reduces the clearance rate by eliminating a high mannose glycosylation site, and mutation in residues 296-299 causes limitation to interaction with PAI- $1 .^{70}$ In humans, the half-life of tenecteplase is 18 minutes $^{71,72}$ and compared to alteplase and reteplase, tenectplase is more efficacious than alteplase and reteplase and can be administered as a single bolus. ${ }^{6}$

\section{B. Urokinase or urokinase-type plasminogen} activator (uPA). Urokinase is a two chain serine protease and used as a thrombolytic agent in the treatment of pulmonary embolism, coronary artery thrombosis, IV catheter clearance, and venous and arterial blood clots. It is also known as urokinasetype plasminogen activator (uPA) and contains 411 amino acid residues. It is secreted as a single chain glycoprotein named prourokinase (sc-uPA) from endothelial cells, macrophages, renal epithelial cell and some tumor cells. This sc-uPA is converted to a two chain derivative (tc-uPA) following cleavage at Lys158-Ile159 peptide bond by plasmin or kallikrein. ${ }^{73,74}$ uPA has 3 domains: (i) an epidermal growth factor like domain, (ii) a single plasminogen like kringle and (iii) a serine protease domain. ${ }^{75} \mathrm{But}$ none of these are responsible for binding tc-uPA to fibrin. As a result, it has a low affinity for fibrin relative to tPA and its effectiveness is not affected by the presence or absence of fibrin. ${ }^{76,77}$ In contrast to the less binding capacity of tc-uPA to fibrin, sc-uPA shows a large binding capacity to fibrin but it has a very low plasminogen activating capacity than that of tc-uPA $(<1 \%) .{ }^{19}$ It converts plaminogen to plasmin and has an elimination half life of 12-20 minutes. Initially, urokinase was purified from human urine but now it is produced by tissue culture techniques and recombinant DNA techniques (expressed in $E$ coli). It was withheld from the United States market by USFDA in 1998 due to safety issue, but then reintroduced in the market in 2002.

C. Streptokinase. Streptokinase is a first generation thrombolytic agent obtained from Streptococcus sp. and is moderately efficacious in practice. It is included in the list of World Health Organization Model List of Essential Medicines. ${ }^{78}$ It 
clears approximately 50\% of occluded coronary arteries within 90 minutes and reduces mortality upto $25 \%$ when administered intravenously. ${ }^{79}$ Streptokinase has a molecular mass of $47 \mathrm{kDa}$ consisting of 414 amino acid (aa) residues. ${ }^{80}$ It was revealed by the crystal structure that SK contains three sequential domains $^{81}$, namely $\alpha$ (aa 1 to 150 ), $\beta$ (aa 151 to 287), and $\gamma$ (aa 288 to 411 ) domains from the amino to the carboxy-termini, linked by flexible loops. ${ }^{35}$ SK does not have any proteolytic activity as of itself, instead forms a 1:1 stochiometric complex with a plasminogen or a plasmin molecule. ${ }^{82} \mathrm{SK}$ is an indirect plasminogen activator. SK is the drug of choice for thrombolytic therapy, particularly in developing countries, because of its cost effectiveness. As the plasmin, produced through the SK-mediated activation of plasminogen, acts not only on the fibrin network of the thrombus, but also on the SK itself, the in-vivo half-life of SK is limited to about 30 minutes. $^{83}$

D. Staphylokinase (SAK). Staphylokinase (SAK), is a clot specific plasminogen activator obtained from Staphylococcus aureus consisting of 136 amino acid. Even though this specific clot buster found good response in therapy, its use is limited because of its antigenicity and short half-life. ${ }^{83}$

E. Nattokinase. The fibrinolysis mechanism of NK has been explored more extensively than other microbial fibrinolytic enzymes. NK carries out fibrinolytic activity in multiple mechanisms. i) It directly cleaves cross-linked fibrin as its properties largely resemble that of tPA, ii) It activates the production of tPA, which converts inactive plasminogen to active plasmin. ${ }^{84,85}$ Furthermore, NK enhances its fibrinolysis through cleavage and inactivation of the primary inhibitor of fibrinolysis, PAI-1, and regulates total fibrinolytic activity by its relative ratio with tPA. ${ }^{86} \mathrm{NK}$ is well-absorbed across the intestinal tract after intraduodenal administration to induce fibrinolysis. ${ }^{87}$

Various characteristics of different thrombolytic agents are compred in Table 3..$^{29,88,89}$

\section{Biosimilar thrombolytic agents}

According to FDA, "A biosimilar product is a biological product that is approved based on a showing that it is highly similar to an FDA-approved biological product, known as a reference product, and has no clinically meaningful differences in terms of safety and effectiveness from the reference product. Only minor differences in clinically inactive components are allowable in biosimilar products."As biosimilars (also known as subsequent entry biologics, biogenerics, or biocomparables) are not exactly the same as the originator's product, they are not considered as true generics, but rather are only compared to the originator's product biologically and clinically. Biosimilars are intended to be characterized as to demonstrate a high degree of similarity to the reference product rather than demonstrate clinical benefit and are used at the same dose and for the same indication as the reference productlike true generics. ${ }^{90}$

Although no biosimilars are approved in Europe, a great boom of biosimilars is developing in Asia to reduce the high cost of biologics and increased financial burden of Asian governments. ${ }^{91}$ A large number of biosimilars are also available in other countries like Russia, Canada, etc. Myokinase (company- Biocon) and Shankinase (company Shantha Biotechnics) are approved biosimilar of streptokinase in India. Shankinase was approved in 2004. Biosimilar of reteplase, MiRel from Reliance Life Sciences was approved in 2009 in India. ${ }^{92,93}$ Elaxim is a biosimilar of tenecteplase from Emcure pharmaceuticals Ltd. which was marketed in 2012 in India. Different marketed thrombolytics and some of their biosimilars are listed in table 4 .

\section{Bacillus sp. as a Source of thrombolytic and fibrinolytic proteases}

The thrombolytic agents obtained from bacterial sources are considered safe, and the administration of these fibrinolytic agents upon oral administration could increase fibrinolytic activity in human plasma. ${ }^{94}$ That is why, these enzymes, especially from the genus Bacillus, could be useful to develop 
potent thrombolytic agents. ${ }^{95}$ Bacillus is a genus of Gram-positive rod-shaped endospore forming bacteria which is a member of the division Firmicutes and produce extracellular proteases during postexponential and stationary phases under most culture conditions. ${ }^{8}$ Bacilli have a great diversity of strains. These strains need different nutritional medium that some may grow well in a solution of glucose, ammonium phosphate and a few mineral salts, some need additional growth factors or amino acids, and others require increasingly complex nutrition. ${ }^{96}$ Large-scale production of enzymes such as amylases and proteases is possible because of their ability to excrete these enzymes. ${ }^{97}$ Different traditional fermented foods are important sources of genus
Bacillus that have been found to produce the fibrinolytic enzymes. ${ }^{36}$ In 1987, B. natto was first screened from a traditional Japanese soybeanfermented food named natto which produces nattokinase NK. ${ }^{98}$ After that, some other bacilli from different fermented foods were discovered (Table 5). Morever, Bacillus sp. possessing thrombolytic and fibrinilytic properties have also been isolated from other sources including soils recently. For example, recently extracellular enzymes produced by a mutated form of Bacillus sp., Bacillus licheniformis EMS-O-1 which was isolated from feather decomposed soil have been reported to have thrombolytic activities. ${ }^{99}$

Table 4. Different marketed thrombolytics and their biosimilars.

\begin{tabular}{|c|c|c|c|c|c|}
\hline Drug names & $\begin{array}{l}\text { Originator's } \\
\text { brand names }\end{array}$ & Originator & Indication & Biosimilars version & Biosimilar players \\
\hline Alteplase & Activase ${ }^{\circledR}$ & Genentech & $\begin{array}{l}\text { Catheter thrombosis, } \\
\text { Myocardial infarction, } \\
\text { Pulmonary embolism, } \\
\text { Stroke }\end{array}$ & Alteplase - Nanogen & $\begin{array}{l}\text { Nanogen } \\
\text { Biopharmaceutical Co }\end{array}$ \\
\hline \multirow[t]{3}{*}{ Reteplase } & Rapilysin $® ;$ & Roche; Developer: & Myocardial infarction, & MiRel; R TPR 004 & Reliance Life Sciences \\
\hline & Retavase $®$ & $\begin{array}{l}\text { Allergan; Chiesi } \\
\text { USA; EKR } \\
\text { Therapeutics }\end{array}$ & Discontinued embolism & $\begin{array}{l}\text { BM 06022; r PA; } \\
\text { Rapilysin; Retavase }\end{array}$ & $\begin{array}{l}\text { Shanghai Fudan- } \\
\text { Zhangjiang Bio- } \\
\text { Pharmaceutical; } \\
\text { Developer: Shandong } \\
\text { Ahua Biochemical }\end{array}$ \\
\hline & & & & $\begin{array}{l}\text { Reteplase biosimilar- } \\
\text { Nanogen } \\
\text { Biopharmaceutical }\end{array}$ & $\begin{array}{l}\text { Nanogen } \\
\text { Biopharmaceutical Co }\end{array}$ \\
\hline Tenecteplase & $\begin{array}{l}\text { Metalyse®; } \\
\text { RG3625; } \\
\text { TNK; TNK- } \\
\text { tPA; } \\
\text { TNKase }\end{array}$ & $\begin{array}{l}\text { Genentech; } \\
\text { Developer: } \\
\text { Boehringer } \\
\text { Ingelheim; } \\
\text { Genentech; Roche } \\
\text { Canada }\end{array}$ & $\begin{array}{l}\text { Myocardial infarction, } \\
\text { Discontinued, Catheter } \\
\text { thrombosis, Heart arrest }\end{array}$ & Elaxim & $\begin{array}{l}\text { Emcure pharmaceuticals } \\
\text { Ltd. }\end{array}$ \\
\hline \multirow[t]{4}{*}{$\begin{array}{l}\text { Streptokinase } \\
\text { suppository - } \\
\text { Heber Biotec }\end{array}$} & $\begin{array}{l}\text { Proctokinase } \\
\text {; rSK } \\
\text { suppository - } \\
\text { Heber Biotec }\end{array}$ & $\begin{array}{l}\text { Center for Genetic } \\
\text { Engineering and } \\
\text { Biotechnology: } \\
\text { Developer: Heber } \\
\text { Biotec }\end{array}$ & Haemorrhoids & Sedonase & Sedico \\
\hline & & & & $\begin{array}{l}\text { Myokinase; } \\
\text { Recombinant } \\
\text { streptokinase - } \\
\text { Biocon }\end{array}$ & Biocon \\
\hline & & & & Prokinase & $\begin{array}{l}\text { Emcure pharmaceuticals } \\
\text { Ltd. }\end{array}$ \\
\hline & & & & Shankinase & Shantha Biotechnics \\
\hline
\end{tabular}


Table 5. Fibrinolytic enzyme producing Bacilli from different traditional foods.

\begin{tabular}{|c|c|c|c|c|}
\hline Microorganism & Source & Origin & Name of enzyme & References \\
\hline B. natto & Natto & Japan & Nattokinase & Fujita et al., $1993^{100}$ \\
\hline Bacillus sp. CK & Chungkook-jang & Korea & $\mathrm{CK}$ & Kim et al., $1996^{101}$ \\
\hline Bacillus sp. KA38 & Jeot-gal & Korea & Jeot-gal enzyme & Kim et al., $1997^{102}$ \\
\hline B. subtilis IMR-NK1 & Natto & Taiwan & - & Chang et al., $2000^{103}$ \\
\hline Bacillus sp. DJ-4 & Doen-jang, & Korea & Subtilisin DJ-4 & Kim and Choi, $2000^{104}$ \\
\hline B. amyloliquefaciens DC-4 & Douchi & China & Subtilisin DFE & Peng et al., $2003^{105}$ \\
\hline B. subtilis QK02 & Fermented soybean & - & $\mathrm{QK}-1$ and $\mathrm{QK}-2$ & Ko et al., $2004^{106}$ \\
\hline B. firmus NA-1 & Natto & Japan & - & Seo and Lee, $2004^{107}$ \\
\hline Bacillus sp. DJ-2 & Doen-jang & Korea & bpDJ-2 & Choi et al., $2005^{108}$ \\
\hline Bacillus sp. & $\begin{array}{l}\text { Fermented shrimp paste } \\
\text { products }\end{array}$ & Vietnam & - & $\begin{array}{l}\text { Anh et al., } 2013^{109} \text {, } \\
\text { Anh } \text { et al., } 2015^{110}\end{array}$ \\
\hline B. coagulans & Terasi and Jambal roti & Indonesia & - & Prihanto et al., $2013^{111}$ \\
\hline Bacillus sp. & Chao Vinh Phong & Vietnam & - & Linh et al., $2013^{112}$ \\
\hline- & Fermented fish paste products & Vietnam & - & Uyen et al., $2013^{113}$ \\
\hline B. amyloliquefaciens & $\begin{array}{l}\text { Traditional soybean- } \\
\text { fermented products }\end{array}$ & Vietnam & - & Huy et al., $2016^{114}$ \\
\hline
\end{tabular}

Table 6. Bacilli from various agro-industrial substrate showing thrombolytic activity.

\begin{tabular}{|c|c|c|c|c|c|}
\hline Microorganisms & Substrate & $\begin{array}{l}\text { Specific } \\
\text { activity } \\
(\mathrm{U} / \mathrm{mg})^{*}\end{array}$ & $\begin{array}{l}\text { Purification } \\
\text { fold* }\end{array}$ & $\begin{array}{l}\text { Yield } \\
(\%)^{*}\end{array}$ & Reference \\
\hline Bacillus subtilis & Soybean curd residues & - & - & - & $\mathrm{Zu}$ et al., $2010^{118}$ \\
\hline Bacillus amyloliquefaciens & Chick peas & - & - & - & Wei et al., $2011^{119}$ \\
\hline Bacillus subtilis & Red bean & - & - & - & Chang et al., $2012^{59}$ \\
\hline Bacillus altitudinis GVC11 & Castor husk & - & - & - & Madhuri et al., $2012^{120}$ \\
\hline Virgibacillus sp. SK 37 & Brewery yeast sludge & - & - & - & Lapsongphon et al., $2013^{121}$ \\
\hline Bacillus subtilis I-2 & Soybean meal & 135.75 & 4.8 & 10.4 & Bajaj et al., $2014^{122}$ \\
\hline B. amyloliquefaciens FCF-11 & Corn husk & $23,862.8$ & 443.5 & 17 & Kotb, $2014^{123}$ \\
\hline Bacillus cereus IND1 & Wheat bran & 235 & 3.1 & 19.9 & $\begin{array}{l}\text { Vijayaraghavan and Vincent, } \\
2014^{124}\end{array}$ \\
\hline Bacillus subtilis & Chick peas & 115239 & 38.07 & 9.08 & Xiao et al., $2014^{125}$ \\
\hline Bacillus cereus IND5 & cow dung & - & - & - & Biji et al., $2016^{126}$ \\
\hline B. halodurans IND18 & Wheat bran & 501.8 & 3.6 & 20.4 & Vijayaraghavan et al., $2016^{115}$ \\
\hline Bacillus sp. & cow dung & - & - & - & Vijayaraghavan et al., $2017^{127}$ \\
\hline IND12 & & & & & \\
\hline
\end{tabular}

* DEAE cellulose.

Production of bacterial thrombolytic and fibrinolytic enzymes from agro-industrial wastes

Enzymes can be produced by submerged fermentation $(\mathrm{SmF})$ and solid state fermentation (SSF). SSF has many advantages over SmF.$^{95}$ In SSF, fibrinolytic enzymes are produced using many substrates (Table 6). Cost and availability of the substrates, and nutrient composition of the selected solid waste are the main criteria for the selection of an ideal substrate for SSF. Cow dung medium may be considered as a promise and in expensive substrate for fibrinolytic enzyme production. Normally, $80 \%$ moisture content is maintained for the production of fibrinolytic enzyme. In SSF, moisture content is one of the critical factors. ${ }^{15}$ Cow dung substrate has high moisture-holding capacity, which facilitates the 
production of fibrinolytic enzyme from bacterial species. The optimum moisture content for enzyme production may vary depending on the organism and substrate used in SSF process. ${ }^{116}$ Various carbon and nitrogen sources were used for enhanced production of fibrinolytic enzyme. ${ }^{15}$ It was revealed that maximum fibrinolytic enzyme production is favored by starch, followed by sucrose. This result was in agreement with the previous study on proteolytic enzymes from Bacillus sp. ${ }^{117}$

\section{CONCLUSION}

In this review, protease enzymes with their classifications, therapeutic uses, uses as thrombolytic and fibrinolytic agents have been discussed. Different microbial sources of proteases including bacterial proteases as well as their relative studies and production from traditional fermented foods have also been highlighted. Microbial thrombolytic and fibrinolytic enzymes have attracted much more medical interest in recent decades. Proteases produced by Bacillus sp. have been identified to possess thrombolytic and fibrinolytic activities. These proteases are mainly serine proteases such as nattokinase, subtilisin, etc. Exploration of these microbes, specially Bacillus sp. may come out with potential sources of enzymes of pharmaceutical and industrial interests.

\section{REFERENCES}

1. Kuddus, M. and Ramteke, P.W. 2012. Recent developments in production and biotechnological applications of coldactive microbial proteases. Crit. Rev. Microbiol. 38, 330-338.

2. Barett, A.J. 1994. Classification of peptidases. Methods. Enzymol. 244, 1-5.

3. Alnahdi, H.S. 2012. Isolation and screening of extracellular proteases produced by new Isolated Bacillus sp. J. App. Pharm. Sci. 2, 071-074.

4. Oda, K. 2012. New families of carboxyl peptidases: serinecarboxyl peptidases and glutamic peptidases. $J$. Biochem. 151, 13-25.

5. Duffy, M.J., McGowan, P.M. and Gallagher, W.M. 2008. Cancer invasion and metastasis: changing views. $J$. Pathol. 214, 283-293.
6. Craik, C.S., Pag M.J. and Madison, E.L. 2011. Proteases as therapeutics. Biochem. J. 435, 1-16.

7. Rao, C.S., Sathish, T., Pendyala, B., Kumar, T.P. and Prakasham, R.S.2009. Development of a mathematical model for Bacillus circulans growth and alkaline protease production kinetics. J. Chem. Technol. Biotechnol. 84, 302307.

8. Bhunia, B., Basak, B. and Dey, A. 2012. A review on production of serine alkaline protease by Bacillus spp.J. Biochem. Tech. 3, 448-457.

9. Simkhada, J.R., Mander, P., Cho, S.S. and Yoo, J.C. 2010. A novel fibrinolytic protease from Streptomyces sp. CS684. Process Biochem. 45, 88-93.

10. Mine, Y., Wong, A.H.K. and Jiang, B. 2005. Fibrinolytic enzymes in Asian traditional fermented foods. Food Res. Int. 38, 243-250.

11. Lopez-Sendon, J., de Lopez, S.E., Bobadilla, J.F., Rubio, R., Bermejo, J. and Delcan, J.L. 1995. Cardiovascular pharmacology (XIII). The efficacy of different thrombolytic drugs in the treatment of acute myocardial infarct. Rev. Esp. Cardiol. 48, 407-439.

12. Lillicrap, D., Key, N., Makris, M. and O'Shaughnessy, D. 2009. Practical Hemostasis and Thrombosis. WileyBlackwell. pp. 1-5.

13. Furie, B. and Furie, B.C. 2005. Thrombus formation in vivo. J. Clin. Invest. 115, 3355-62.

14. Rivera, J., Lozano, M.L., Navarro-Núñez, L. and Vicente, V. 2009. Platelet rfeceptors and signaling in the dynamics of thrombus formation. Haematologica 94, 700-711.

15. Pallister, C.J. and Watson, M.S. 2010. Haematology. Scion Publishing. pp. 336-347.

16. Hoffbrand, A.V. 2002. Essential haematology. Oxford: Blackwell Science. pp. 241-243.

17. Coughlin, S.R. 2000. Thrombin signaling and proteaseactivated receptors. Nature. 407, 258-264.

18. Cardigan, R.A., McGloin, H., Mackie, I.J., Machin, S.J. and Singer, M. 1999. Activation of the tissue factor pathway occurs during continuous venovenous hemofiltration. Kidney Int. 55, 1568-1574.

19. Hajjar K. A., 2003b. The molecular basis of fibrinolysis. In: Hematology of Infancy and Childhood (ed. by Nathan, D.G., Orkin, S.H., Ginsburg D.and Look, A.T.), W.B. Saunders Co., Philadelphia, USA. pp. 1497-1514.

20. Entrez Gene: plasminogen

21. Miyata, T., Iwanaga, S., Sakata, Y. and Aoki, N. 1982. Plasminogen Tochigi: inactive plasmin resulting from replacement of alanine- 600 by threonine in the active site. Proc. Natl. Acad. Sci. U.S.A. 79, 6132-6. 
22. Forsgren, M., Råden, B., Israelsson, M., Larsson, K. and Hedén, L.O. 1987. Molecular cloning and characterization of a full-length cDNA clone for human plasminogen. FEBS Lett. 213, 254-60.

23. Law, R.H., Caradoc-Davies, T., Cowieson, N., Horvath, A.J., Quek, A.J., Encarnacao, J.A., Steer, D., Cowan, A., Zhang, Q., Lu, B.G., Pike, R.N., Smith, A.I., Coughlin, P.B. and Whisstock, J.C. 2012. The X-ray crystal structure of fulllength human plasminogen. Cell Rep. 1, 185-90.

24. Cesarman-Maus, G. and Hajjar, K.A. 2005. Molecular mechanisms of fibrinolysis. Br.J. Heamatol. 129, 307-21.

25. Medved, L. and Nieuwenhuizen, W. 2003. Molecular mechanisms of initiation of fibrinolysis by fibrin. Thromb. Haemostasis 89, 409-419.

26. Dugdale, D., Cesarman-Maus, G. and Hajjar, K.A. 2011. Primary or secondary fibrinolysis. Retrieved. MedlinePlus.

27. Zhang, J., Ma, G., Lv, Z., Zhou, Y., Wen, C., Wu, Y. and Xu, R. 2014. Targeted thrombolysis strategies for neuroprotective effect. Neural Regen Res. 9, 1316-22.

28. Kirmani, J.F., Alkawi, A., Panezai, S. and Gizzi, M. 2012. Advances in thrombolytics for treatment of acute ischemic stroke. Neurology 79, S119-125.

29. Kumar, A., Pulicherla, K.K., Ram, K.S. and Rao, K.R.S.S. 2010. Evolutionary Trend of Thrombolytics. Int. J. Bio-Sci. Technol. 2, 51-68.

30. Collen, D. and Lijnen, H.R. 2004. Tissue-type plasminogen activator: a historical perspective and personal account. $J$. Thromb. Haemost. 2, 541-546.

31. Duffy, M.J. 2002. Urokinase plasminogen activator and its inhibitor, PAI-1, as prognostic markers in breast cancer: from pilot to level 1 evidence studies. Clin. Chem. 48, 1194-1197.

32. Chen, H.M., Guan, A.L. and Markland, F.S. 1991. Immunological properties of the fibrinolytic enzyme (fibrolase) from southern copperhead (Agkistrodon contortrix contortrix) venom and its purification by immunoaffinity chromatograph. Toxicon. .29, 683-694.

33. Mihara, H., Sumi, H., Yoneta, T., Mizumoto, H., Ikedo, R., Seiki, M. and Maruyama, M. 1991. A novel fibrinolytic enzyme extracted from the earthworm Lumbricus rubellus. Jpn. J. Physiol. 41, 461-472.

34. Liu,J., Xing, J., Chang, T., Ma, Z. and Liu, H. 2005. Optimization of nutritional conditions for nattokinase production by Bacillus natto NLSSE using statistical experimental methods. Process Biochem. 40, 2757-2762.

35. Wang, X., Tang, J., Hunter, B. and Zhang, X.C. 1999. Crystal structure of streptokinase $\beta$ - domain. FEBS Letters. 459, 85-89.
36. Peng, Y., Yang, X. and Zhang, Y. 2005. Microbial fibrinolytic enzymes: an overview of source, production, properties, and thrombolytic activity in vivo. Appl. Microbiol. Biotechnol. 69, 126-32.

37. Egorov, N.S., Kochetov, G.A. and Khaidarova, N.V. 1976. Isolation and properties of the fibrinolytic enzyme from the Actinomyces thermovulgaris cultural broth. Mikrobiologiia. 45, 455-459.

38. Egorov, N.S., Prianishnikova, N.I., Al-Nuri, M.A. and Aslanian, R. 1985. Streptomyces spheroides M8-2 strain-a producer of extracellular proteolytic enzyme possessing fibrinolytic and thrombolytic action. Naucn. Dokl. Vyss. Sk. Biol. Nauki. 1, 77-81.

39. Chitte, R.R. and Dey, S. 2000. Potent fibrinolytic enzyme from a thermophilic Streptomyces megasporus strain SD5. Lett. Appl. Microbiol. 31, 405-410.

40. Chitte, R.R. and Dey, S. 2002. Production of fibrinolytic enzyme by thermophilic Streptomyces Species. World J. Microbiol. Biotechnol. 18, 289-294.

41. Jeong, Y.K., Park, J.U., Baek, H., Park, S.H., Kong, I.S., Kim, D.W. and Joo, W.H. 2001. Purification and biochemical characterization of a fibrinolytic enzyme from Bacillus subtilis BK-17. World J. Microbiol. Biotechnol. 17, 89-92.

42. Jeong, Y.K., Kim, J.H., Gal, S.W., Kim, J.E., Park, S.S., Chung, K.T., Kim, Y.H., Kim, B.W. and Joo, W.H. 2004. Molecular cloning and characterization of the gene encoding a fibrinolytic enzyme from Bacillus subtilis Strain A1. World J. Microbiol. Biotechnol. 20, 711-717.

43. Kho, C.W., Park, S.G., Cho, S., Lee, D.H., Myung, P.K. and Park, B.C. 2005. Confirmation of Vpr as a fibrinolytic enzyme present in extracellular proteins of Bacillus subtilis. Protein Expr. Purif. 39, 1-7.

44. Nidialkova, N.A., Matseliukh, O.V. and Varbanets, L.D. 2012. Isolation of Bacillus thuringiensis IMVB-7324 fibrinolytic peptidase. Microbiol. Z. 74, 9-15.

45. Nidialkova, N.A., Matseliukh, O.V. and Varbanets, L.D. 2013. Physicochemical properties of Bacillus thuringiensis IMVB-7324 fibrinolytic peptidase. Mikrobiol. Z. 75, 3-7.

46. Vijayaraghavan, P. and Vincent, S.G.P. 2014 (1). Medium optimization for the production of fibrinolytic enzyme by Paenibacillus sp. IND8 using response surface methodology. The Scientific World Journal. 1-9.

47. Vijayaraghavan, P. and Vincent, S.G.P. 2014 (2). Statistical optimization of fibrinolytic enzyme production by Pseudoalteromonassp. IND11 using cow dung substrate by response surface methodology. Springer Plus. 3: 60.

48. Taneja, K., Bajaj, B.K., Kumar, S. and Dilbaghi, N. 2017. Production, purification and characterization of fibrinolytic enzyme from Serratia sp. KG-2-1 using optimized media.3 Biotech. 7, 184-187 
49. Vijayaraghavan, P. and Vincent, S.G.P. 2015. A low cost fermentation medium for potential fibrinolytic enzyme production by a newly isolated marine bacterium, Shewanella sp. IND20. Biotechnol. Rep.7, 135-142.

50. Batomunkueva, B.P. and Egorov, N.S. 2001. Isolation, purification and resolution of the extracellular proteinase complex of Aspergillus ochraceus 513 with fibrinolytic and anticoagulant activities. Microbiology. 70, 519-522.

51. Abdel-Fattah, A.F.and Ismail, A.S. 1984. Purification and some properties of pure Cochliobolus lunatus fibrinolytic enzyme. Biotechnol. Bioeng. 26, 407-411.

52. Tao, S., Peng, L., Beihui, L., Deming, L. and Zuohu, L. 1997. Solid state fermentation of rice chaff for fibrinolytic enzyme production by Fusarium oxysporum. Biotechnol. Lett. 19, 465-467.

53. Tao, S., Peng, L., Beihui, L., Deming, L. and Zuohu, L. 1998. Successive cultivation of Fusarium oxysporum on rice chaff for economic production of fibrinolytic enzyme. Bioprocess Eng. 18, 379-381.

54. El-Aassar, S.A., El-Badry, H.M. and Abdel-Fattah, A.F. 1990. The biosynthesis of proteases with fibrinolytic activity in immobilized cultures of Penicillium chrysogenum H9. Appl. Microbiol. Biotechnol. 33, 26-30.

55. El-Aassar, S.A. 1995. Production and properties enzyme in solid state cultures of Fusarium pallidoroseum. Biotechnol. Lett. 17, 943-948.

56. Rashad, M.M., Mahmoud, A.E., Al-Kashef, A.S. and Nooman, M.U. 2012. Purification and Characterization ofa Novel Fibrinolytic Enzyme by Candida guilliermondii Grown on Sunflower Oil Cake. J. Appl. Sci. Res. 8, 635-645.

57. Choi, H.S. and Shin, P.H. 1998. Purification and partial characterization of a fibrinolytic protease in Pleurotus ostreatus. Mycologia. 90, 674-679.

58. Xiao-Lan, L., Lian-Xiang, D., Fu-Ping, L., Xi-Qun, Z. and Jing, X. 2005. Purification and characterization of a novel fibrinolytic enzyme from Rhizopus chinensis 12. Appl. Microbiol. Biotechnol. 67, 209-214.

59. Chang, C.T., Wang, P.M., Hung, Y.F. and Chung, Y.C. 2012. Purification and biochemical properties of a fibrinolytic enzyme from Bacillus subtilis - fermented red bean. Food Chem. 133, 1611-1617.

60. Matsubara, K., Sumi, H., Hori, K. and Miyazawa, K. 1998. Purification and characterization of two fibrinolytic enzymes from a marine green alga, Codium intricatum. Comp. Biochem. Physiol. Biochem. Mol. Biol. 119, 177-181.

61. Matsubara, K., Hori, K., Matsuura, Y. and Miyazawa, K. 1999. A fibrinolytic enzyme from a marine green alga, Codium latum. Phytochemistry. 52, 993-999.

62. Pennica, D., Holmes, W.E., Kohr, W.J., Harkins, R.N., Vehar, G.A., Ward, C.A., Bennet, W.F., Yelverton, E., Seeburg, P.H., Heyneker, H.L., Goeddel, D.V.and Collen, D. 1983. Cloning and expression of human tissue-type plasminogen activator cDNA in E. coli. Nature 301, 214-221.
63. Tate, K.M., Higgins, D.L., Holmes, W.E., Winkler, M.E., Heyneker, H.L. and Vehar, G.L. 1987. Functional role of proteolytic cleavage at arginine-275 of human tissue plasminogen activator as assessed by site-directed mutagenesis. Biochemistry 26, 338-343.

64. Hajjar, K.A. 2003a. The endothelium in thrombosis and hemorrhage. In: Thrombosis and Hemorrhage (ed. by Loscalzo, J. and Schaefer, A.I.). Lippincott Williams and Wilkins, Philadelphia, USA. pp. 206-219.

65. Wardlaw, J.M., Murray, V., Berge, E., del Zoppo, G., Sandercock, P., Lindley, R.L. and Cohen, G. 2012. Recombinant tissue plasminogen activator for acute ischaemic stroke: an updated systematic review and metaanalysis. Lancet. 379, 2364-2372.

66. Tsikouris, J.P.1 and Tsikouris, A.P. 2001. A review of available fibrin-specific thrombolytic agents used in acute myocardial infarction. Pharmacotherapy 21, 207-217.

67. Andreasen, P.A., Egelund, R. and Petersen, H.H. 2000. The plasminogen activation system in tumor growth, invasion, and metastasis. Cell. Mol. Life Sci. 57, 25-40.

68. Bode, C., Smalling, R.W., Berg, G., Burnett, C., Lorch, G., Kalbfleisch, J.M., Chernoff, R., Christie, L.G., Feldman, R.L., Seals, A.A. and Weaver, W.D. 1996. Randomized comparison of coronary thrombolysis achieved with doublebolus reteplase (recombinant plasminogen activator) and front-loaded, accelerated alteplase (recombinant tissue plasminogen activator) in patients with acute myocardial infarction. Circulation 94, 891-898.

69. Smalling, R.W. 1996. Molecular biology of plasminogen activators: what are the clinical implications of drug design? Am. J. Cardiol. 78, 2-7.

70. Madison, E.L., Goldsmith, E.J., Gerard, R.D., Gething, M.J. and Sambrook, J.F. 1989. Serpin-resistant mutants of human tissue-type plasminogen activator. Nature 339, 721-724.

71. van de Werf, F., Adgey, J., Ardissino, D., Armstrong, P.W., Aylward, P., Barbash, G., Betriu, A., Binbrek, A.S., Califf, R. and Diaz, R. 1999. Single-bolus tenecteplase compared with front-loaded alteplase in acute myocardial infarction: the ASSENT-2 double-blind randomised trial. Lancet 354, 716722.

72. Cannon, C.P., Gibson, C.M., McCabe, C.H., Adgey, A.A., Schweiger, M.J., Sequeira, R.F., Grollier, G., Giugliano, R.P., Frey, M. and Mueller, H.S. 1998. TNK-tissue plasminogen activator compared with front-loaded alteplase in acute myocardial infarction: results of the TIMI10B trial. Circulation 98, 2805-2814.

73. Holmes, W.E., Pennica,D., Blaber, M., Rey, M.W., Giinzler, W.O., Steffens, G.J. and Heynecker, H.L. 1985. Cloning and expression of the gene for pro-urokinase in Escherichia coli. Biotechnology 3, 923-929

74. Riccio, A., Grimaldi, G., Verde, P., Sebastio, G., Boast, S. and Blasi, F. 1985. The human urokinase-plasminogen activator gene and its promoter. Nucleic Acids Res. 13, 27592771. 
75. Kasai, S., Arimura, H., Nishida, M. and Suyama, T. 1985. Primary structure of single-chain pro-urokinase. J. Biol. Chem. 260, 12382-12389.

76. Gurewich, V., Pannell, R., Louie, S., Kelley, P., Suddith, R.L. and Greenlee, R. 1984. Effective and fibrin-specific clot lysis by a zymogen precursor from urokinase (prourokinase). A study in vitro and in two animal species. $J$. Clin. Invest. 73, 1731-1739.

77. Lijnen, H.R., Zamarron, C., Blaber, M., Winkler, M. and Collen D. 1986. Activation of plasminogen by pro-urokinase J. Biol.Chem. 261, 1253-1258.

78. Mohammad Reza, N., Mohammed Hossein, M., Mohammed, B. and Mahmood, C. 2007. Cloning and Overexpression of Active Recombinant Fusion Streptokinase: A New Approach to Facilitate Purification. Pak. J. Biol. Sci. 10, 2146- 2151.

79. Collen, D. and Lijnen, H.R. 1991. Basic and clinical aspects of fibrinolysis and thrombolysis. Blood. 78, 3114-3124.

80. Malke, H. and Ferretti, J.J. 1984. Streptokinase: cloning, expression and excretion by Escherichia coli. Proc. Natl. Acad. Sci. (USA). 81, 3557-3561.

81. Lizano, S. and Johnston, K.H. 2005. Structural Diversity of Streptokinase and Activation of Human Plasminogen. Infect. Immun. 73, 4451-4453

82. Zhai, P., Wakeham, N.K., Loy, J.A. and Zhang, X.C. 2003. Functional roles of streptokinase C-terminal flexible peptide in active site formation and substrate recognition in plasminogen activation. Biochemistry 42, 114-120.

83. Wu, X.C., Ye, R.Q., Duan, Y.J. and Wong, S.L. 1998. Engineering of plasmin-resistant forms of streptokinase and their production in Bacillus subtilis: streptokinase with longer functional half-life. Appl. Environ. Microbiol. 64, 824-829.

84. Fujita, M., Ito, Y., Hong, K. and Nishimuro, S. 1995c. Characterization of nattokinase-degraded products from human fibrinogen or cross-linked fibrin. Fibrinolysis. 9, 157-164.

85. Kumada, K., Onga, T. and Hoshino, H. 1994. The effect of natto possessing a high fibrinolytic activity in human plasma. Igaku To Seibutsugaku. 128, 117-119.

86. Urano, T., Ihara, H., Umemura, K., Suzuki, Y., Oike, M., Akita, S., Tsukamoto, Y., Suzuki, I. and Takada, A.2001. The profibrinolytic enzyme subtilisin NAT purified from Bacillus subtilis cleaves and inactivates plasminogen activator inhibitor type 1. J. Biol. Chem. 276, 24690-24696.

87. Fujita, M., Hong, K. and Ito, Y. 1995a. Transport of nattokinase across the rat intestinal tract. Biol. Pharm. Bull. 18, 1194-1196.

88. Ghosh, M., Pulicherla, K.K., Rekha, V.P.B., Rao, G.V. and Rao, K.R.S.S. 2012. A review on successive generations of streptokinase based thrombolytic agents. Int. J. Pharm. Pharm. Sci. 4, 38-42.

89. Meretoja, A. and Tatlisumok, T. 2006. Thrombolytic therapy in acute ischemic stroke-Basic concept. Current Vascular Pharmacology 4, 31-44.
90. Weise, M., Bielsky, M.C., De Smet, K., Ehmann, F., Ekman, N., Giezen, T.J., Gravanis, I., Heim, H.K., Heinonen, E., Ho, K., Moreau, A., Narayanan, G., Kruse, N.A., Reichmann, G., Thorpe, R., van Aerts, L., Vleminckx, C., Wadhwa, M. and Schneider, C.K.2012. Biosimilars: what clinicians should know. Blood. 120, 5111-5117.

91. Wen-Chan, Tsai. 2017. Update on Biosimilars in Asia. Curr. Rheumatol. Rep. 19, 47

92. GaBI Online - Generics and Biosimilars Initiative. 'Similar biologics' approved and marketed in India. 2015. Mol., Belgium: Pro. Pharma. Commun. Int.

93. Jayaraman, K. 2010. India's Cipla sets sights on Avastin, Herceptin and Enbrel. Nature Biotechnol. 28, 883-884.

94. Sumi, H., Hamada, H., Nakanishi, K. and Hiratani, H. 1990. Enhancement of the fibrinolytic activity in plasma by oral administration of nattokinase. Acta. Haematol. 84, 139-143.

95. Pandey, A., Soccol, C.R., Nigam, P., Brand, D., Mohan, R. and Roussos S. 2000. Biotechnological potential of coffee pulp and coffee husk for bioprocesses. Biochem. Eng. J. 6, 153-162.

96. Laskin, A.I. and Lechevalier, H.A. 1973. Handbook of Microbiology. CRC Press, USA.

97. Moon, S.H. and Parulekar, S.J. 1991. A parametric study of protease production in batch and fed-batch cultures of Bacillus firmus. Biotechnol. Bioeng. 37, 467-483.

98. Sumi, H., Hamada, H., Tsushima, H., Mihara, H. and Muraki, H. 1987. A novel fibrinolytic enzyme (nattokinase) in the vegetable cheese Natto; a typical and popular soybean food in the Japanese diet. Experientia. 43, 1110-1111.

99. Asad uz Zaman, M., Al Mamun, M.A., Khan, S.N., Hoq, M.M. and Mazid, M.A. 2016. Partial Purification of Alkaline Protease as Thrombolytic Agent from Mutant Strain Bacillus licheniformis EMS250-O-1. Dhaka Univ. J. Pharm. Sci. 15, 135-141.

100. Fujita, M., Nomura, K., Hong, K., Ito, Y., Asada, A. and Nishimuro, S. 1993. Purification and characterization of a strong fibrinolytic enzyme (nattokinase) in the vegetable cheese natto, a popular soybean fermented food in Japan. Biochem. Biophys. Res. Commun.197, 1340-1347.

101. Kim, W., Choi, K., Kim, Y., Park, H., Choi, J., Lee, Y., Oh, H., Kwon, I. and Lee, S. 1996. Purification and characterization of a fibrinolytic enzyme produced from Bacillus sp. strain CK 11-4 screened from Chungkook-Jang. Appl. Environ. Microbiol. 62, 1488-2482.

102. Kim, H.K., Kim, G.T., Kim, D.K., Choi, W.A., Park, S.H., Jeong, Y.K. and Kong, I.S. 1997. Purification and characterization of a novel fibrinolytic enzyme from Bacillus sp. KA38 originated from fermented fish. J. Ferment. Bioeng. 84, 307-312.

103. Chang, C.T., Fan, M. H., Kuo, F. C. and Sung, H. Y. 2000. Potent fibrinolytic enzyme from a mutant of Bacillus subtilis IMR-NK1. J. Agric. Food Chem. 48, 3210-3216. 
104. Kim, S.H. and Choi, N.S. 2000. Purification and characterization of subtilisin DJ-4 secreted by Bacillus sp. strain DJ-4 screened from Doen-Jang. Biosci. Biotechnol. Biochem. 64, 1722-1725.

105. Peng, Y., Huang, Q., Zhang, R.H. and Zhang, Y.Z. 2003. Purification and characterization of a fibrinolytic enzyme produced by Bacillus amyloliquefaciens DC-4 screened from douchi, a traditional Chinese soybean food. Comp. Biochem. Physiol. Biochem. Mol. Biol. 134, 45-52.

106. Ko, J.H., Yan, J.P., Zhu, L. and Qi, Y.P. 2004. Identification of two novel fibrinolytic enzymes from Bacillus subtilis QK02. Comp. Biochem. Physiol. C. Toxicol. Pharmacol. 137, 65-74.

107. Seo, J.H. and Lee, S.P. 2004. Production of fibrinolytic enzyme from soybean grits fermented by Bacillus firmus NA-1. J. Med. Food..7, 442-449.

108. Choi, N.S., Yoo, K.H., Hahm, J.H., Yoon, K.S., Chang, K.T., Hyun, B.H., Maeng, P.J. and Kim, S.H. 2005. Purification and characterization of a new peptidase, bacillopeptidase DJ2, having fibrinolytic activity: produced by Bacillus sp. DJ-2 from Doen-Jang. J. Microbiol. Biotechnol. 15, 72-79.

109. Anh, D.N.Q., Huy, D.N.A. and Hung, P.V. 2013. Optimization of growing conditions for the production of fibrinolytic enzymes by Bacillus subtilis using response surface methodology. Proceedings of National Conference of Biotechnology. pp. 30-34. Natural and Technology Science Publisher: Hanoi, Vietnam.

110. Anh, D.B.Q., Mi, N.T.T., Huy, D.N.A., and Hung, P.V. 2015. Isolation and optimization of growth condition of Bacillus sp. from fermented shrimp paste for high fibrinolytic enzyme production. Arab. J. Sci. Engg. 40, 23-28.

111. Prihanto, A.A., Darius, and Firdaus, M. 2013. Proteolytic and fibrinolytic activities of halophilic lactic acid bacteria from two Indonesian fermented foods.J. Microbiol. Biotechnol. Food. Sci. 2, 2291-2293.

112. Linh, D.N., Minh, N.V., Giau, P.T.N., Ngan, V.T., Phu, D.V. and Dong, T.C. 2013. Selection of bacteria producing fibrinolytic enzyme from fermented soy food. Proceeding of National Conference of Biotechnology. Natural and Technology Science Publisher: Hanoi, Vietnam. pp. 652-657.

113. Uyen, N.Q., Thao, T.Q., Ha, P.T., Quyen, N.H.M. and Lan, V.T.T. 2013. Investigation of some bacteria owning nattokinase activity from traditional food in Vietnam. Proceeding of National Conference of Biotechnology. Natural and Technology Science Publisher: Hanoi, Vietnam. pp. 560-564.

114. Huy, D.N.A., Hao, P.A. and Hung, P.V. 2016.Screening and identification of Bacillus sp. isolated from traditional Vietnamese soybean-fermented products for high fibrinolytic enzyme production. Int. Food Res. J. 23, 326-331.

115. Vijayaraghavan, P., Vincent, S.G.P., Arasu, M.V. and AlDhabi, N.A. 2016. Bioconversion of agro-industrial wastes for the production of fibrinolytic enzyme from Bacillus halodurans IND18: Purification and biochemical characterization. Electron. J. Biotechnol. 20, 1-8.
116. Prakasham, R.S., Rao, C.S. and Sarma, P.N. 2006. Green gram husk- an inexpensive substrate for alkaline protease production by Bacillus sp. in solid-state fermentation. Bioresour. Technol. 97, 1449-1454.

117. Sepahy, A.A. and Jabalameli, L. 2011. Effect of culture conditions on the production of an extracellular protease by Bacillus sp. isolated from soil sample of lavizan jungle park. Enzyme Res. 2011, 1-7.

118. Zu, X., Zhang, Z., Yang, Y., Che, H., Zhang, G. and Li, J. 2010. Thrombolytic activities of nattokinase extracted from Bacillus subtilis - fermented soybean curd residues. Int. J. Biol. 2, 120-125.

119. Wei, X., Luo, M., Xu, L., Zhang, Y., Lin, X., Kong, P. and Liu, H. 2011. Production of fibrinolytic enzyme from Bacillus amyloliquefaciens by fermentation of chickpeas, with the evaluation of the anticoagulant and antioxidant properties of chickpeas. J. Agric. Food Chem. 59, 3957-3963.

120. Madhuri, A., Nagaraju, B., Harikrishna, N. and Reddy, G. 2012. Production of alkaline protease by Bacillus altitudinis GVC11 using castor husk in solid-state fermentation. Appl. Biochem. Biotechnol. 167, 1199-1207.

121. Lapsongphon, N., Rodtong, S. and Yongsawatdigul, J. 2013. Spent brewery yeast sludge as a single nitrogen source for fibrinolytic enzyme production of Virgibacillus sp. SK37. Food Sci. Biotechnol. 22, 71-78.

122. Bajaj, B.K., Singh, S., Khullar, M., Singh, K., and Bhardwaj, S. 2014. Optimization of fibrinolytic protease production from Bacillus subtilis I-2 using agro-residues. Braz. Arch. Biol. 57, 653-662.

123. Kotb, E. 2014. Purification and partial characterization of a chymotrypsin-like serine fibrinolytic enzyme from Bacillus amyloliquefaciens FCF-11 using corn husk as a novel substrate. World J. Microbiol. Biotechnol. 30, 2071-2080.

124. Vijayaraghavan, P. and Vincent, S.G.P. 2014. Statistical optimization of fibrinolytic enzyme production using agroresidues by Bacillus cereus IND1 and its thrombolytic activity in vitro. Biomed. Res. Int. 2014, 1-11.

125. Xiao, P., Yao, S., Rizwan-ur-rehman, Kang, R. and Wang, Y. 2014. A Fibrinolytic Enzyme Produced by Bacillus subtilis Using Chickpea (Cicer arietinum L.) as Substrate.Adv. J. Food Sci. Technol . 6, 1294-1300.

126. Biji, G.D., Arun, A., Muthulakshmi, E., Vijayaraghavan, P., Arasu, M.V. andAl-Dhabi, N.A. 2016. Bio-prospecting of cuttle fish waste and cow dung for the production of fibrinolytic enzyme from Bacillus cereus IND5 in solid state fermentation. Biotech. 6, 231.

127. Vijayaraghavan, P., Rajendran P., Vincent, S.G.P., Arun, A., Al-Dhabi, N.A., Arasu, M.V., Kwon, O.Y.and Kim Y.O. 2017. Novel Sequential Screening and Enhanced Production of Fibrinolytic Enzyme by Bacillus sp. IND12 Using Response Surface Methodology in Solid-State Fermentation. Biomed. Res. Int. 2017, 1-13. 